\section{Atomic scientist to advise India's defence minister}

DR RAJA RAMANNA, the director of the Bhabha Atomic Research Centre at Trombay in Bombay, has been appointed scientific adviser to India's Minister of Defence. The appointment appears to have provoked some controversy. Before it was officially confirmed, press reports spoke of $\mathrm{Dr}$ Ramanna's "abrupt removal", which a Defence Department spokesman later said was misleading as he had been sounded out some months previously. But The Times of India has called it a "wrong decision" and "certainly one of the worst cases of pushing round pegs into square holes". Other reports have described scientists at the Bhabha research centre as gloomy at the news.

The main cencern has been over the future of the centre itself, which Dr Ramanna has led for six years. He is regarded as the "father" of India's nuclear capability-it was the Bhabha centre which successfully exploded an underground nuclear device in May 1974 at Pokaran in the western state of Rajasthan, helping to precipitate international concern over the growing trade in nuclear technology. The Times of India's fear is that Dr Ramanna's transfer will adversely affect staff morale and that the centre will "recede into the background of routine, uninspired work'.

The basis for the suggestion that Dr Ramanna has been a less than willing appointee appears to be that he has been offered the post before and refused it because of his personal wish to remain a working scientist. At the centre he has presided over five research reactors and ancillary plants including a fuel element fabrication facility and a reprocessing plant. Also under his control have been a reactor research centre for fast reactor development in Madras, and a cyclotron in Calcutta.

Nuclear-related policy in India is in the hands of $\mathrm{Mr}$ Morarji Desai, the Prime Minister. He cleared the way for resumed co-operation on nuclear research with Canada after the Rajasthan explosion when he gave $\mathrm{Mr}$ Pierre Trudeau, the Canadian Prime Minister, assurances last year that there would be no more nuclear tests even for peaceful purposes. The other vexed nuclear issue in India, the resumption of supplies of enriched uranium from the United States for the Tarapur nuclear power station in the State of Maharashtra, now lies in the hands of the US Nuclear Regulatory Commission (NRC), which has to grant the export licence. President Carter has already sanctioned the awaited shipment.

\section{Agricultural efficiency}

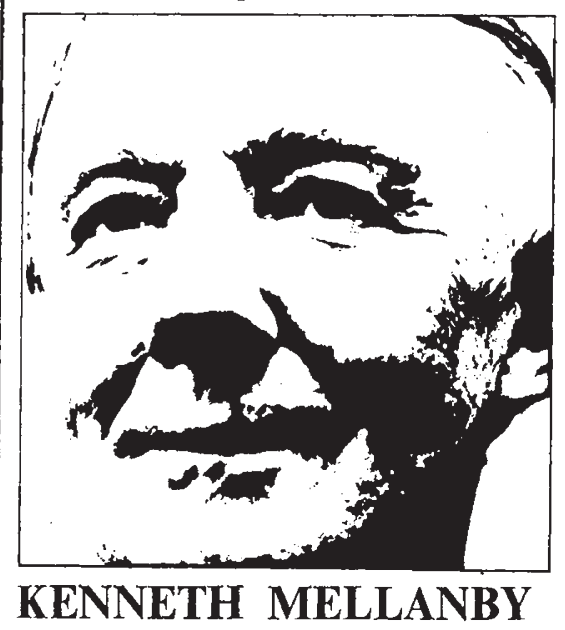

As an examiner, I find it difficult to decide how to mark a script when a student includes serious errors in his answer, if it is obvious that he is repeating something he has been taught in his lecture course. Recently I have been marking a question about artificial manures, and all the answers report, rightly, that nitrogenous fertilisers take a lot of energy, generally derived from oil, in their manufacture. The trouble arises when actual figures are quoted, and conclusions are derived from those figures.

I was told by almost all the members of one batch of students that to produce the chemical fertiliser needed to grow one hectare of maize on a modern farm in the United States took 50 tonnes, or 70,000 litres, of oil. This figure is about 250 times too high. Even though this is what they had been taught the figure is so absurd that some marks must be lost. I think that the student should have realised that this amount of oil would cost several thousands of pounds, vastly more than the value of the five tonnes of grain harvested. The most serious result of the overestimate of the energy used to produce the fertiliser is that it gives an entirely false picture of world agriculture, its needs and its potentials.

If we examine the statement that artificial fertilisers are energyintensive products, we find that each tonne of nitrogen applied to the soil took aproximately 1.8 tonnes of oil equivalent in its manufacture. Intensively grown maize is given aproximately $125 \mathrm{~kg}$ of nitrogen per hectare. In Britain wheat, producing 4 tonnes per hectare, receives about $100 \mathrm{~kg}$ of nitrogen. For the maize this is the energy equivalent of $200 \mathrm{~kg}$ of oil, one fifth of a tonne. The figure for wheat is a little lower. Had my students used these data, their answers might have been differently slanted.

If we look at these figures from our own point of view, we see that four tonnes of wheat could supply more than half the calories and much of the protein needed by twenty-four British adults in a year. The nitrogenous fertiliser used to grow one man's ration would be produced by using two gallons of oil-about 50 miles of motoring in a family car.

The richer countries can obviously afford this, but what about the developing countries? We read, and my students repeat in their examination papers, that if the type of farming practiced in Europe and North America were exported worldwide, it would consume $40 \%$ of the world's total energy budget. This figure is very misleading, for it is based mainly on a vast increase in intensive animal husbandry. If all farmers used synthetic nitrogen at the UK or USA rate to grow cereals, only something in the region of one hundred million tonnes of oil would be needed for its production. This is a tiny fraction of global consumption.

I would not advocate that all countries followed our example. Both they and we should make better use of our animal excreta and other organic manures, even if producing and spreading them may use more energy than chemical fertilisers. Where there is ample manpower it is foolish to mechanise and produce intolerable unemployment. There is much we can all learn from the traditional agricultural practices of China and other eastern countries. But we must have agricultural policies based on positive concepts and not on nonsensical figures about agricultural energetics.

\section{Kosmos strikes 1000}

Kosmos-1000, the latest member of the long-running Soviet space series, went into orbit on March 31.

The Kosmos series, inaugurated in March 1962, was originally announced as being for astrophysical/geophysical research. Over the years, its range has gradually been extended "in the service of the national economy". Accordingly,
Kosmos-1000 is "intended for the working out of a space-navigation system, in order to ensure the determination of the location of ships of the naval and fishing fleets at any point of the world ocean".

A review of the Kosmos satellite programme to date will appear in our next issue. 